\title{
Keefektifan Telenomus remus (Nixon) (Hymenoptera: Scelionidae) Dalam Mengendalikan Hama Tanaman Bawang Daun Spodoptera exigua Hübner (Lepidoptera: Noctuidae)
}

\author{
DAMAYANTI BUCHOR1, ERNA DWI HERAWATI, ADHA SARI \\ Departemen Hama dan Penyakit Tumbuhan, Fakultas Pertanian, \\ Institut Pertanian Bogor
}

(diterima Mei 2008, disetujui Agustus 2008)

\begin{abstract}
The Effectiveness of Telenomus remus (Nixon) (Hymenoptera: Scelionidae) for Controling Welsh Onion Pest Spodoptera exigua Hübner (Lepidoptera: Noctuidae). The objective of this research is to study the effectiveness of $T$. remus as biocontrol agent for $S$. exigua. The study was conducted by releasing a set of $T$. remus females on potted onion plants that have been attacked by $S$. exigua. Three different parasitism level was artificially created by releasing different numbers of females: low rate parasitism (release of 4 adult females), moderate parasitism ( 7 females) and high parasitism level (11 females). The result of this study showed that $T$. remus is effective to control $S$. exigua population.. Up to $48.2 \%$ of $S$. exigua. population was able to be suppressed by the high parasitism level. Rate of parasitisation was more when more adult female $T$. remus was released. Release of 11 adult female of $T$. remus can increase the population level of the parasitoid up to 24.1 times than the initial population. This express that T. remus is a mortality factor which can regulate the population of $S$. exigua. However, the succesfull parasitisation of $T$. remus is also dependent on environmental factors such as temperature, humidity, food, and host suitability.
\end{abstract}

KEY WORDS: Telenomus remus, Spodoptera exigua, welsh onion, biological control, egg parasitoid.

\section{PENDAHULUAN}

Spodoptera exigua dilaporkan menyerang tanaman bawang sebagai tanaman inang utama (Kalshoven 1981). Begitu telur menetas larva menyerang daun (Wibowo 1999). Menurut Himawati (1998) pada serangan yang berat daun tampak terpotong-potong sehingga menurun- kan kuantitas dan kualitas hasil panen. Telur S. exigua diletakkan secara berkelompok dan setiap kelompok telur rata-rata 63,42 butir. Satu generasi $S$. exigua menghabiskan waktu 29,88 hari (Rudiana 1995). Menurut Metcalf \& Flint (1982) imago S. exigua meletakkan telur rata-rata 500-600 butir dalam waktu 4-10 hari.

Pengendalian hayati merupakan salah satu komponen pengendalian 
hama terpadu yang dewasa ini terus ditingkatkan peranannya. Pengendalian hayati merupakan taktik pengendalian alamiah, karena menggunakan faktor pengendali yang sudah ada di alam yaitu musuh alami dari organisme yang dikendalikan (Hartini 1995). Sari (1997) melaporkan bahwa salah satu musuh alami yang berpotensi mengendalikan $S$. exigua adalah Telenomus spp. Waktu perkembangan telur Telenomus spodopterae didalam telur S. exigua adalah 15 jam, larva 3 hari, prapupa 1 hari, pupa 5-6 hari, dan imago muncul 9-11 hari setelah peletakkan telur. Selama hidupnya imago betina dapat memarasit 45 telur S. exigua. Menurut Yang et al. (1993) dalam Nurmayanti (1998), peletakkan telur dan kemunculan imago parasitoid meningkat pada suhu $15-30^{\circ} \mathrm{C}$, tapi menurun pada suhu $35^{\circ} \mathrm{C}$.

Penelitian mengenai Telenomus sp. di Indonesia sejauh ini berkisar pada penelitian mengenai pengaruh inang pada kebugaran di laboratorium (Buchori et al.1997) dan pengaruh suhu terhadap kemampuan parasitisasi dan kebugaran (Pujiastuti 2001 \& Sari 2001). Penelitian mengenai kemampuan Telenomus spp. dalam mengendalikan populasi inangnya belum banyak diteliti, padahal untuk aplikasi pengendalian hayati di lapang, selain informasi kebugaran diperlukan juga data mengenai kemampuan Telenomus spp. untuk mengendalikan inangnya.
Fokus dari penelitian ini adalah mempelajari keefektifan $T$. remus dalam mengendalikan $S$. exigua dan melihat peluang keberhasilan hidup populasi $S$. exigua pada tingkat parasitisasi $T$. remus yang berbeda.

\section{BAHAN DAN METODE}

Penelitian dilaksanakan sejak bulan April - Agustus 2003 di Laboratorium Bioekologi Parasitoid dan Predator, Departemen Hama dan Penyakit Tumbuhan, Fakultas Pertanian, Institut Pertanian Bogor.

S. exigua diambil dari pertanaman bawang daun di daerah Cipanas, Jawa Barat. S. exigua dibiakkan dalam wadah plastik yang dialasi kertas buram dan diberi makan daun bawang segar. Makanan diganti setiap hari. Larva instar akhir dipindahkan ke wadah plastik yang telah diberi serbuk gergaji setebal $2 \mathrm{~cm}$. Hal ini dimaksudkan agar larva instar terakhir dapat membentuk pupa didalam serbuk gergaji tersebut. Imago yang muncul dipindahkan ke wadah plastik besar yang pinggir dan alasnya diberi kertas buram dan diatasnya ditutup tissue. Imago diberi pakan madu yang telah diencerkan $10 \%$. Telur-telur yang diletakkan imago betina diambil untuk diparasit oleh parasitoid dan ada yang ditetaskan untuk perbanyakan. Telur yang digunakan dalam perlakuan adalah telur yang berumur satu hari.

Parasitoid T. remus dipelihara dalam tabung reaksi $(\mathrm{p}=10 \mathrm{~cm}, \mathrm{~d}=1,5$ 
$\mathrm{cm})$. Pemeliharaan dilakukan dengan cara memasukkan beberapa paket telur S. exigua ke dalam tabung sebagai inangnya dan diberi pakan madu yang diolesi ke dinding tabung sebagai makanannya. Paket telur diganti dengan yang baru setiap hari sampai imago parasitoid mati. T. remus akan muncul dari telur yang terparasit setelah 10 hari. Parasitoid yang muncul dipindahkan ke tabung baru dengan cara menemukan mulut tabung yang berisi parasitoid dengan mulut tabung yang baru.

\section{Pelaksanaan penelitian}

Penelitian dilakukan dengan melepaskan $T$. remus pada tiga tingkatan populasi (3 perlakuan) dan 1 kontrol yang diulang sebanyak 5 kali. Perlakuan yang dimaksud yaitu pemberian T. remus pada tingkat parasitisasi (TP) tinggi (11 imago betina), TP sedang (7 imago betina) dan TP rendah (4 imago betina), sedangkan untuk kontrol tidak diberikan $T$. remus. Pemberian $T$. remus dilakukan secara dua tahap. Perlakuan dilakukan dengan memasukkan satu tanaman bawang daun yang sudah ditanam di polibag dan berdaun banyak ke dalam kurungan plastik $(\mathrm{d}=$ $22 \mathrm{~cm}, \mathrm{t}=57 \mathrm{~cm}, \mathrm{tbl}=0,5 \mathrm{~mm})$. Sepasang imago $S$. exigua dimasukkan kedalamnya dan setelah 24 jam serangga parasitoid $T$. remus dimasukkan ke dalam kurungan plastik yang didalamnya sudah terdapat telur S. exigua. Setelah 3 hari, tanaman bawang daun diambil dari kurungan dan diganti dengan tanaman yang baru disertai dengan pemberian $T$. remus dengan jumlah yang sama, sedangkan S. exigua tidak diganti. Telur $S$. exigua yang terparasit digunting dan diletakkan di dalam tabung untuk mengetahui jumlah imago T. remus yang muncul, sedangkan telur yang tidak terparasit dibiarkan menetas menjadi larva $S$. exigua. Tanaman yang sudah dikeluarkan dari kurungan dan sudah diteluri oleh S. exigua dipotong dan diletakkan di dalam kotak plastik berukuran (14.5 $\mathrm{x} 10) \mathrm{cm}^{2}$ yang kemudian dipelihara dan dihitung jumlah $S$. exigua yang mampu hidup dan yang mati dari siklus hidupnya (dari larva instar awal sampai imago) setiap hari. Telur $S$. exigua yang tidak terparasit, menjadi larva dipelihara didalam kotak plastik berukuran $(14.5 \mathrm{x} 10) \mathrm{cm}^{2}$, yang bagian atasnya di lubangi dan di tutup dengan kain kassa agar larva memperoleh udara. Larva setiap hari diberi makan daun bawang segar, sampai instar akhir. Menjelang pupa bagian dasar wadah plastik diberi serbuk gergaji dan dipelihara sampai menjadi imago.

\section{Persentase parasitisasi $T$. remus}

Persentase parasitisasi (PP) dihitung dengan rumus:

$$
\mathrm{PP}=\frac{\Sigma \text { telur terparasit }}{\Sigma \text { total telur }} \times 100 \%
$$




\section{Perkembangan populasi $S$. exigua}

Pada tiap perlakuan, perkembangan populasi $S$. exigua dari fase telur hingga imago diikuti dengan menghitung telur, larva dan pupa yang ada. Data kemudian diolah menjadi life table dengan rumus sebagai berikut:

$1_{\mathrm{x}}=$ proporsi yang bertahan hidup disetiap stadia

$$
1_{\mathrm{x}}=\overline{\mathrm{a}_{\mathrm{o}} \text { (jumlah telur) }}
$$

$\mathrm{a}_{\mathrm{x}}=$ jumlah $S$. exigua yang bertahan hidup pada setiap stadia

$\mathrm{d}_{\mathrm{x}}=$ proporsi kematian setiap stadia

$$
\mathrm{d}_{\mathrm{x}}=\mathrm{l}_{\mathrm{x}}-\mathrm{l}_{(\mathrm{x}+1)}
$$

$\mathrm{q}_{\mathrm{x}}=$ angka kematian

$$
\mathrm{q}_{\mathrm{x}}=\frac{\mathrm{d}_{\mathrm{x}}}{\mathrm{l}_{\mathrm{x}}}
$$

\section{Kemunculan imago T. remus}

Kemunculan imago dari telur terparasit dihitung dengan rumus:

Kemunculan imago $(\%)=$

$$
\frac{\Sigma \text { imago yang muncul }}{\Sigma \text { telur terparasit }} \times 100 \%
$$

\section{Nisbah kelamin keturunan}

Nisbah kelamin keturunan dihitung dengan rumus:

Nisbah kelamin $(\%)=$

$$
\frac{\Sigma \text { betina }}{\Sigma \text { betina }+\Sigma \text { jantan }} \times 100 \%
$$

\section{Analisis data}

Rancangan yang digunakan dalam penelitian adalah rancangan acak lengkap (RAL) dengan 1 faktor dan 5 ulangan. Faktor yang dimaksud adalah tingkat parasitisasi rendah, sedang, dan tinggi. Kemudian dilakukan uji Chisquare dengan taraf $\alpha=0,05$.

\section{HASIL DAN PEMBAHASAN}

Data yang diperoleh menunjukkan bahwa rata-rata jumlah telur yang dihasilkan 1 imago $S$. exigua betina per hari adalah 220 butir dan kemampuan 1 imago $T$. remus betina memarasit telur S.exigua per hari adalah 15 butir. Berdasarkan data tersebut dapat diperoleh jumlah $T$. remus yang diperlukan (dengan asumsi bahwa seluruh $T$. remus mampu bertelur). Telur S. exigua dapat terparasit $100 \%$ dengan kehadiran 15 imago betina $T$. remus (15 imago betina $\mathrm{X} \quad 15$ telur/hari), terparasit $75 \%$ dengan kehadiran 11 imago betina, terparasit $50 \%$ dengan kehadiran 7 imago betina, dan terparasit $25 \%$ dengan kehadiran 4 imago betina. Rata-rata lama hidup imago S. exigua adalah 7 hari, sedangkan lama hidup imago $T$. remus adalah 3 hari. Berdasarkan data tersebut maka pelepasan $T$. remus dilakukan 2 tahap agar telur-telur yang dihasilkan imago S. exigua pada hari ke-4 dan selanjutnya masih dapat dikendalikan.

Gambar 1 dan 2 menunjukkan bahwa pada TP tinggi, $T$. remus memarasit telur $S$. exigua lebih banyak dibandingkan pada TP sedang dan TP rendah. Semakin banyak $T$. remus yang dilepaskan, semakin banyak telur S. exigua yang terparasit. Berdasarkan penghitungan jumlah telur yang 


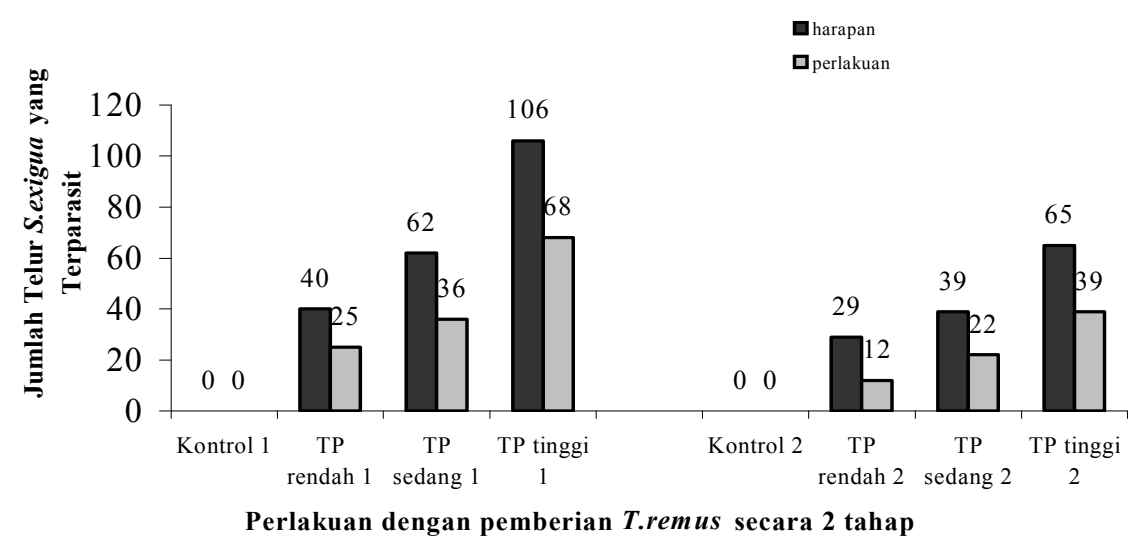

Gambar 1. Perbandingan rata-rata telur S. exigua yang terparasit T. remus antara perlakuan dengan yang diharapkan pada tahap 1 dan 2 pemberian $T$. remus

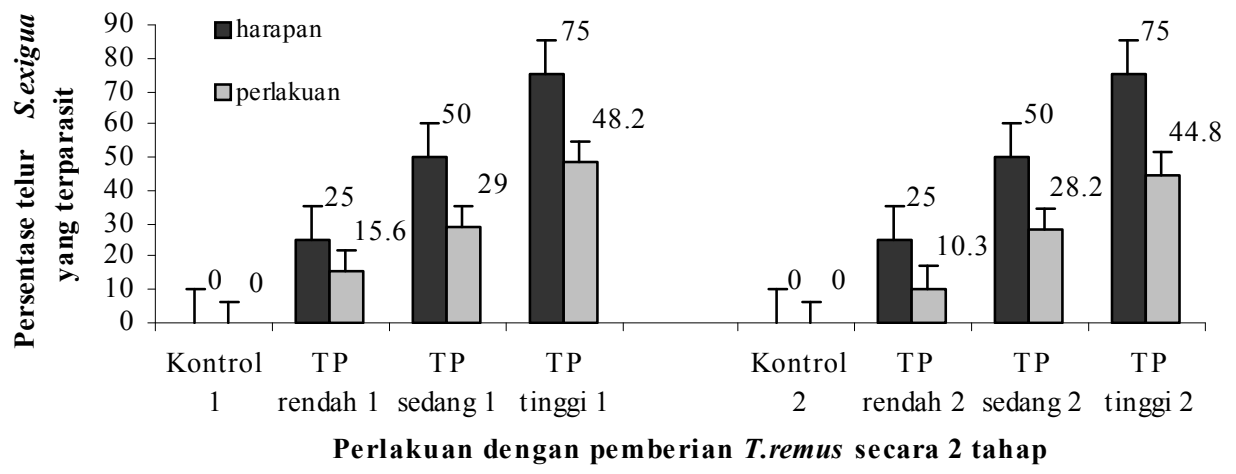

Gambar 2. Perbandingan persentase telur S. exigua yang terparasit T. remus antara perlakuan dengan yang diharapkan pada tahap 1 dan 2

diletakkan dan yang terparasit, maka tingkat parasitisasi secara berturutturut adalah TP tinggi $48,2 \%$ (68 telur terparasit), TP sedang 29\% (36 telur terparasit), dan TP rendah 15,6\% (25 telur terparasit). Pada tahap 2, rata-rata jumlah telur yang terparasit pada perlakuan secara berturut-turut adalah $44,8 \%$ (39 telur terparasit), 28,2\% (22 telur terparasit), dan 10,3\% (12 telur terparasit). Gambar 3 melengkapi kemampuan parasitisasi $T$. remus dengan menunjukkan bahwa dari imago T. remus yang dilepaskan dapat memarasit telur $S$. exigua dengan total jumlah 338 pada TP tinggi, 145 pada TP sedang, 74 pada TP rendah (tahap 1) dan 193 pada TP tinggi, 90 pada TP sedang, dan 39 pada TP rendah (tahap 2). Jumlah telur $S$. exigua yang terparasit pada tahap 1 dan 2 tampak berbeda, hal ini disebabkan karena jumlah telur $S$. exigua yang diproduksi oleh imago $S$. exigua pada kedua tahap tersebut tidaklah sama. Namun, bila diamati dari persentase telur S. exigua 


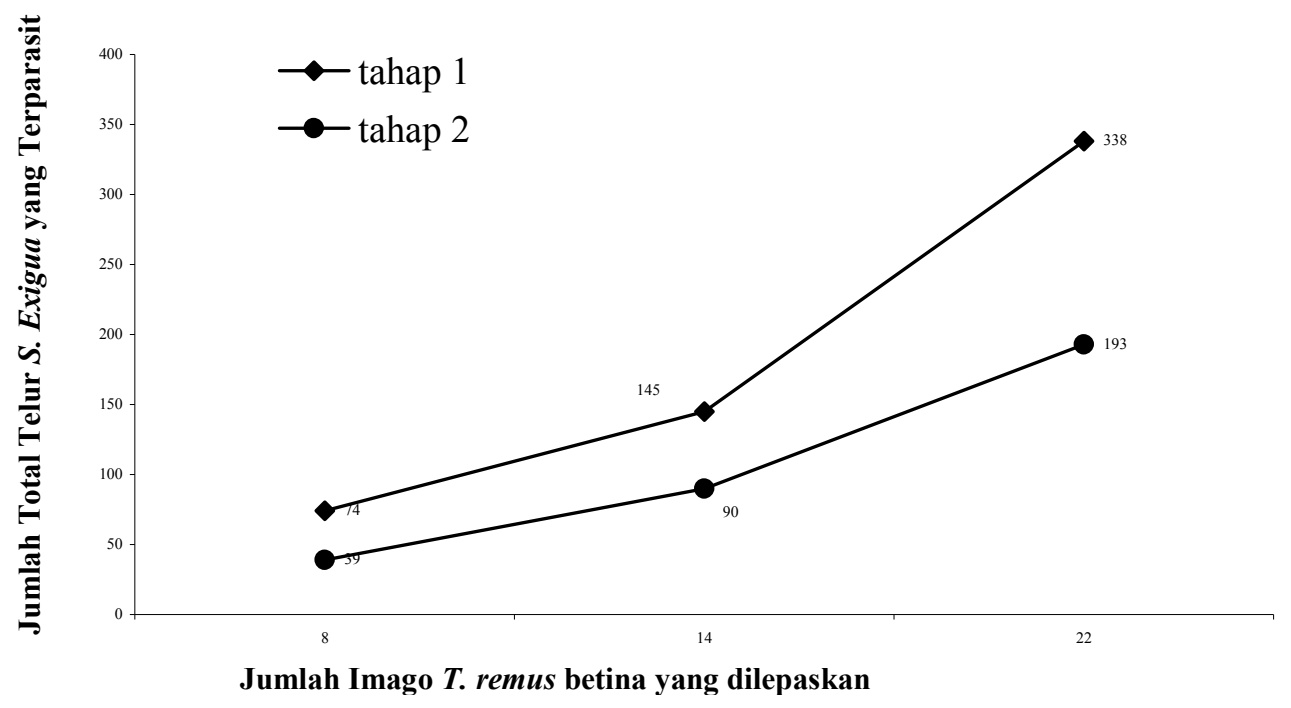

Gambar 3. Kemampuan parasitisasi sejumlah imago T.remus pada telur S.exigua

yang mati tampak bahwa persentase telur $S$. exigua yang terparasit pada kedua tahap tidak berbeda.

Hasil analisis Chisquare menunjukkan bahwa persentase yang diperoleh parasitisasi pada perlakuan sama dengan persentase yang diharapkan (sesuai dengan TP yang telah diasumsikan) kecuali pada perlakuan TP tinggi tahap 1 pemberian T. remus.

Ketahanan populasi $S$. exigua sangat tergantung pada keberhasilan hidup tiap-tiap fase, dari telur, larva, hingga pupa. Perlakuan yang diberikan, pada tahap 1 dan 2 terlihat bahwa pada kontrol, semua telur berhasil menetas menjadi larva instar 1 (100\% hidup). Persentase keberhasilan hidup semakin menurun dengan bertambahnya tingkat stadia. Pada perlakuan TP rendah, sedang, dan tinggi terdapat kematian yang berbeda pada fase telur. Hasil menunjukkan bahwa jumlah telur yang mampu menetas menjadi larva instar 1 pada TP rendah adalah $90,77 \%$, TP sedang 76,57\%, dan TP tinggi 52,06\% (tahap 1) dan TP rendah 93,29\%, TP sedang 76,98\%, dan TP tinggi 55,83\% (tahap 2). Kematian ini juga diikuti pada tiap fase berikutnya, yaitu persentase keberhasilan hidup semakin menurun dengan bertambahnya tingkatan stadia (Gambar 4 dan 5). Kematian yang terjadi pada pertumbuhan populasi $S$. exigua menyebabkan populasi $S$. exigua dari setiap stadia semakin rendah. Kematian S. exigua pada stadia larva hingga imago terlihat cukup tinggi. Tingginya kematian pada stadia larva instar 2 menyebabkan populasi $S$. exigua pada stadia larva instar lanjut menjadi sangat sedikit. 


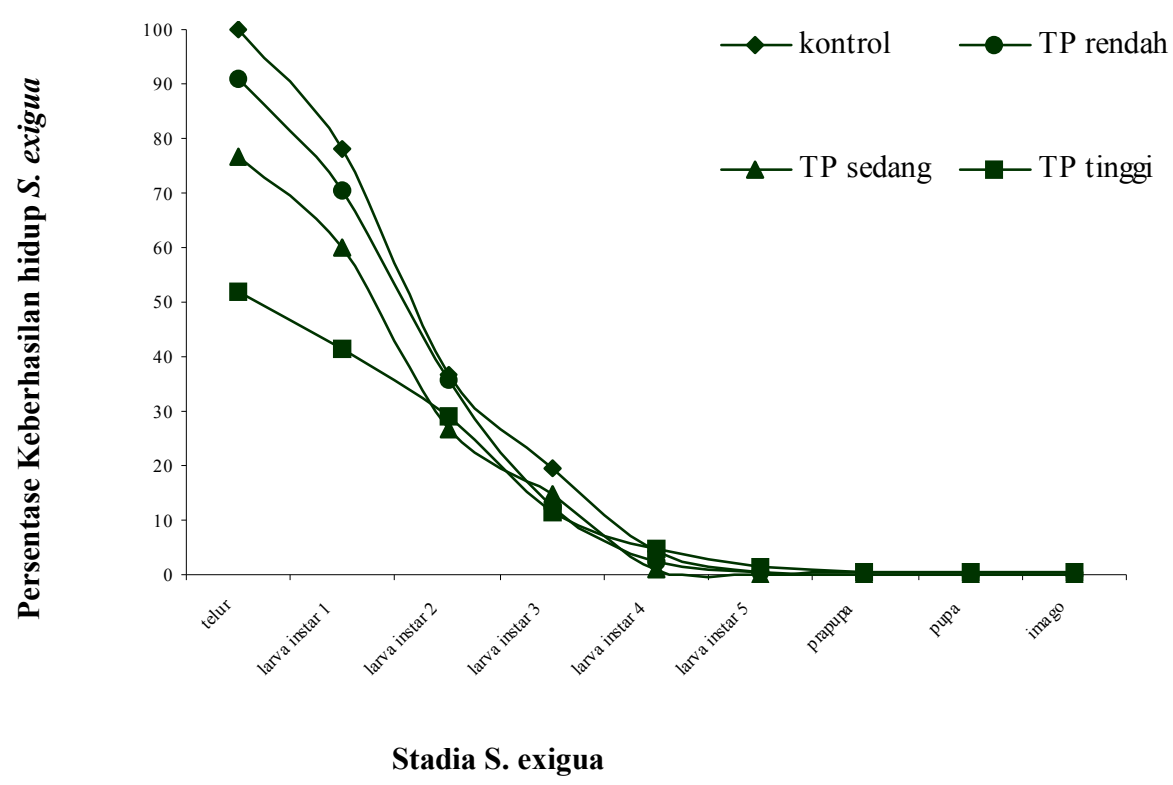

Gambar 4. Persentase keberhasilan hidup populasi S. exigua setiap stadia pada perlakuan yang berbeda tahap 1 pemberian T. remus

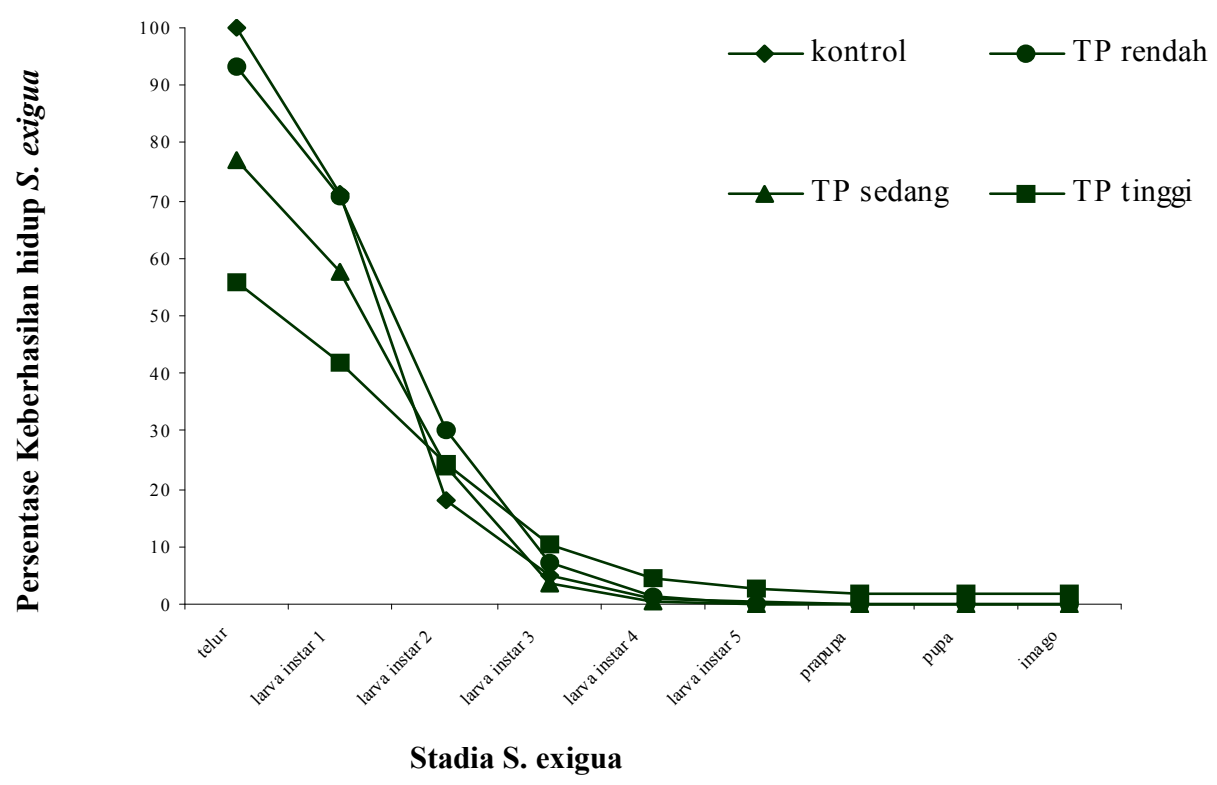

Gambar 5. Persentase keberhasilan hidup populasi $S$. exigua setiap stadia pada perlakuan yang berbeda tahap 2 pemberian T. remus

Tabel 1 dan 2 adalah Tabel menunjukkan bahwa kematian telur kehidupan $T$. remus pada kondisi semakin tinggi dengan semakin laboratorium. Tabel tersebut tingginya tingkat parasitisasi. 
Tabel 1. Kematian populasi S. exigua pada tahap 1 pemberian T. remus

\begin{tabular}{|c|c|c|c|c|c|c|c|c|}
\hline \multirow{2}{*}{ Stadia } & \multicolumn{4}{|l|}{ Kontrol } & \multicolumn{4}{|c|}{ TP rendah } \\
\hline & $a_{x}$ & $1_{x}$ & $\mathrm{~d}_{\mathrm{x}}$ & $\mathrm{q}_{\mathrm{x}}$ & $a_{x}$ & $1_{x}$ & $\mathrm{~d}_{\mathrm{x}}$ & $\mathrm{q}_{\mathrm{x}}$ \\
\hline Telur & 232,20 & 1,00 & 0,000 & 0,000 & 160,40 & 1,000 & 0,092 & 0,092 \\
\hline Larva instar 1 & 232,20 & 1,000 & 0,221 & 0,221 & 145,60 & 0,908 & 0,204 & 0,225 \\
\hline Larva instar 2 & 181,0 & 0,779 & 0,414 & 0,531 & 113,00 & 0,704 & 0,347 & 0,493 \\
\hline Larva instar 3 & 84,80 & 0,365 & 0,170 & 0,466 & 57,20 & 0,357 & 0,232 & 0,649 \\
\hline Larva instar 4 & 45,20 & 0,195 & 0,154 & 0,790 & 20,00 & 0,125 & 0,100 & 0,800 \\
\hline Larva instar 5 & 9,60 & 0,041 & 0,036 & 0,878 & 4,00 & 0,025 & 0,022 & 0,880 \\
\hline Prapupa & 1,20 & 0,005 & 0,000 & 0,000 & 0,60 & 0,003 & 0,003 & 1,000 \\
\hline Pupa & 1,20 & 0,005 & 0,000 & 0,000 & 0,00 & 0,000 & 0,000 & 0,000 \\
\hline Imago & 1,20 & 0,005 & & - & 0,00 & 0,000 & - & - \\
\hline \multirow[t]{2}{*}{ Stadia } & \multicolumn{4}{|l|}{ TP sedang } & \multicolumn{4}{|l|}{ TP tinggi } \\
\hline & $\mathrm{a}_{\mathrm{x}}$ & $1_{\mathrm{x}}$ & $\mathrm{d}_{\mathrm{x}}$ & $\mathrm{q}_{\mathrm{x}}$ & $a_{x}$ & $1_{\mathrm{x}}$ & $\mathrm{d}_{\mathrm{x}}$ & $\mathrm{q}_{\mathrm{x}}$ \\
\hline Telur & 123,80 & 1,000 & 0,234 & 0,234 & 141,00 & 1,000 & 0,480 & 0,480 \\
\hline Larva instar 1 & 94,80 & 0,766 & 0,165 & 0,215 & 73,40 & 0,520 & 0,107 & 0,206 \\
\hline Larva instar 2 & 74,40 & 0,601 & 0,333 & 0,554 & 58,20 & 0,413 & 0,124 & 0,300 \\
\hline Larva instar 3 & 33,20 & 0,268 & 0,119 & 0,444 & 40,80 & 0,289 & 0,176 & 0,609 \\
\hline Larva instar 4 & 18,40 & 0,149 & 0,141 & 0,946 & 16,00 & 0,113 & 0,065 & 0,575 \\
\hline Larva instar 5 & 1,00 & 0,008 & 0,008 & 1,000 & 6,80 & 0,048 & 0,035 & 0,729 \\
\hline Prapupa & 0,00 & 0,000 & 0,000 & 0,000 & 1,80 & 0,013 & 0,010 & 0,769 \\
\hline Pupa & 0,00 & 0,000 & 0,000 & 0,000 & 0,60 & 0,003 & 0,000 & 0,000 \\
\hline Imago & 0,00 & 0,000 & - & - & 0,60 & 0,003 & - & - \\
\hline
\end{tabular}

Ket: $\quad \mathrm{ax}=$ jumlah $S$. exigua yang bertahan hidup pada setiap stadia, $\mathrm{lx}=$ proporsi yang bertahan hidup disetiap stadia, $\mathrm{dx}$ $=$ proporsi kematian setiap stadiaq, $\mathrm{x}=$ angka kematian

Tabel 2. Kematian populasi S. exigua pada tahap 2 pemberian T. remus

\begin{tabular}{|c|c|c|c|c|c|c|c|c|c|c|c|}
\hline \multirow[t]{2}{*}{ Stadia } & \multicolumn{4}{|l|}{ Kontrol } & \multicolumn{7}{|c|}{ TP rendah } \\
\hline & $a_{x}$ & $1_{x}$ & $\mathrm{~d}_{\mathrm{x}}$ & $q_{x}$ & $a_{x}$ & & $1_{x}$ & $\mathrm{~d}$ & $i_{x}$ & & $\mathrm{q}_{\mathrm{x}}$ \\
\hline Telur & 142,60 & 1,000 & 0,000 & 0,000 & \multicolumn{2}{|c|}{116,20} & \multicolumn{2}{|c|}{1,000} & \multicolumn{2}{|c|}{0,067} & 0,0 \\
\hline Larva instar 1 & 142,60 & 1,000 & 0,286 & 0,286 & \multicolumn{2}{|c|}{108,40} & \multicolumn{2}{|c|}{0,933} & \multicolumn{2}{|c|}{0,226} & 0,2 \\
\hline Larva instar 2 & 101,80 & 0,714 & 0,532 & 0,745 & \multicolumn{2}{|c|}{82,20} & \multicolumn{2}{|c|}{0,707} & \multicolumn{2}{|c|}{0,406} & 0,5 \\
\hline Larva instar 3 & 26,00 & 0,182 & 0,130 & 0,714 & \multicolumn{2}{|c|}{35,00} & & & \multicolumn{2}{|c|}{0,227} & 0,7 \\
\hline Larva instar 4 & 7,40 & 0,052 & 0,044 & 0,846 & \multicolumn{2}{|c|}{8,60} & & & \multicolumn{2}{|c|}{0,062} & 0,8 \\
\hline Larva instar 5 & 1,20 & 0,008 & 0,006 & 0,750 & \multicolumn{2}{|c|}{1,40} & & & \multicolumn{2}{|c|}{0,011} & \\
\hline Prapupa & 0,40 & 0,002 & 0,001 & 0,500 & \multicolumn{2}{|c|}{0,20} & & & \multicolumn{2}{|c|}{0,001} & 1, \\
\hline Pupa & 0,20 & 0,001 & 0,000 & 0,000 & \multicolumn{2}{|c|}{0,00} & & \multicolumn{3}{|c|}{0,000} & \\
\hline Imago & 0,20 & 0,001 & - & - & \multicolumn{2}{|c|}{0,00} & & \multicolumn{3}{|c|}{-} & \\
\hline \multirow[t]{2}{*}{ Stadia } & \multicolumn{4}{|c|}{ TP sedang } & \multicolumn{7}{|c|}{ TP tinggi } \\
\hline & $a_{x}$ & $1_{x}$ & $\mathrm{~d}_{\mathrm{x}}$ & $\mathrm{q}_{\mathrm{x}}$ & $a_{x}$ & & & $d_{x}$ & & $\mathrm{q}_{\mathrm{x}}$ & \\
\hline Telur & 78,20 & 1,000 & 0,231 & 0,231 & 87,40 & & & 0,442 & & 0,44 & \\
\hline Larva instar 1 & 60,20 & 0,769 & 0,191 & 0,248 & 48,80 & & & 0,137 & & 0,2 & \\
\hline Larva instar 2 & 45,20 & 0,578 & 0,338 & 0,585 & 36,80 & & & 0,179 & & 0,42 & \\
\hline Larva instar 3 & 18,80 & 0,240 & 0,204 & 0,850 & 21,20 & & & 0,137 & & 0,56 & \\
\hline Larva instar 4 & 2,80 & 0,036 & 0,031 & 0,861 & 9,20 & & & 0,062 & & 0,59 & \\
\hline Larva instar 5 & 0,40 & 0,005 & 0,005 & 1,000 & 3,80 & & & 0,018 & & 0,41 & \\
\hline Prapupa & 0,00 & 0,000 & 0,000 & 0,000 & 2,20 & & & 0,009 & & 0,36 & \\
\hline Pupa & 0,00 & 0,000 & 0,000 & 0,000 & 1,40 & & & 0,000 & & 0,00 & \\
\hline Imago & 0,00 & 0,000 & - & - & 1,40 & & 16 & - & & - & \\
\hline
\end{tabular}

Ket: ax = jumlah $S$. exigua yang bertahan hidup pada setiap stadia, $1 \mathrm{x}=$ proporsi yang bertahan hidup disetiap stadia, $\mathrm{dx}$ $=$ proporsi kematian setiap stadiaq, $\mathrm{x}=$ angka kematian 
Kematian yang cukup tinggi terjadi pada fase larva, prapupa, pupa, dan imago. Namun, dalam perlakuan ini keefektifan $T$. remus dalam mengendalikan populasi $S$. exigua tidak dapat terlihat secara langsung. Berdasarkan hal tersebut maka dibuat suatu model untuk melihat kemampuan $T$. remus dalam menurunkan populasi $S$. exigua (Tabel 3) dengan asumsi jumlah telur yang diletakkan imago $S$. exigua sama seperti pada populasi awal (kontrol). Tabel 3 adalah keefektifan $T$. remus dalam menurunkan populasi $S$. exigua dengan asumsi kematian S.exigua hanya terjadi pada fase telur. Model ini menunjukkan bahwa pada saat $T$. remus memarasit telur $S$. exigua hingga $48 \%, \quad T$. remus mampu menekan populasi $S$. exigua hingga $50 \%$.

Pelepasan populasi $T$. remus yang menyebabkan kematian telur inang hingga 48,2\% (Tahap 1) dan 44,8\% (Tahap 2) ternyata mampu menaikkan populasi $T$. remus hingga 24,1 kali lebih tinggi. Hasil yang didapatkan pada perlakuan lainnya juga menyebabkan peningkatan populasi $T$. remus, pada TP sedang populasi $T$. remus yang menyebabkan kematian hingga $29 \%$ (T1) dan 28,2\% (T2) mampu meningkatkan populasi $T$. remus hingga 16,8 kali, dan pada TP rendah populasi $T$. remus yang menyebabkan kematian hingga 15,6\% (T1) dan 10,3\% (T2) mampu meningkatkan populasi $T$. remus hingga 13,9 kali. Hal ini menunjukkan bahwa $T$. remus sebenarnya merupakan faktor mortalitas yang cukup signifikan dalam penekanan populasi S. exigua (Gambar 6).

Gambar 7 dan 8 menunjukkan bahwa imago T. remus muncul 10-12 hari setelah imago $T$. remus meletakkan telur. Pemberian T. remus pada tahap yang berbeda tidak mempengaruhi persentase kemunculan imago pada kedua tahap tersebut. Terlihat pada gambar bahwa pada tahap 1 dan 2 kemunculan imago T.remus sangat tinggi pada hari ke-10 dan persentase semakin rendah dengan bertambahnya hari (ke-11 dan ke-12). Hal ini terjadi pada kedua tahap

Tabel 3. Keefektifan T. remus menekan populasi S. exigua dengan asumsi kematian hanya terjadi pada fase telur

\begin{tabular}{lcccc}
\hline \hline Perlakuan & $\begin{array}{l}\text { Jumlah telur } S . \\
\text { exigua yang } \\
\text { diletakkan }\end{array}$ & $\mathrm{d}_{\mathrm{x}}$ & $\mathrm{q}_{\mathrm{x}}$ & $\begin{array}{c}\text { Jumlah imago } S . \\
\text { exigua yang } \\
\text { muncul }\end{array}$ \\
\hline Kontrol & 232,20 & 0,000 & 0,000 & 232,20 \\
TP rendah & 232,20 & 0,092 & 0,092 & 210,84 \\
TP sedang & 232,20 & 0,234 & 0,234 & 177,87 \\
TP tinggi & 232,20 & 0,480 & 0,480 & 120,74 \\
\hline
\end{tabular}




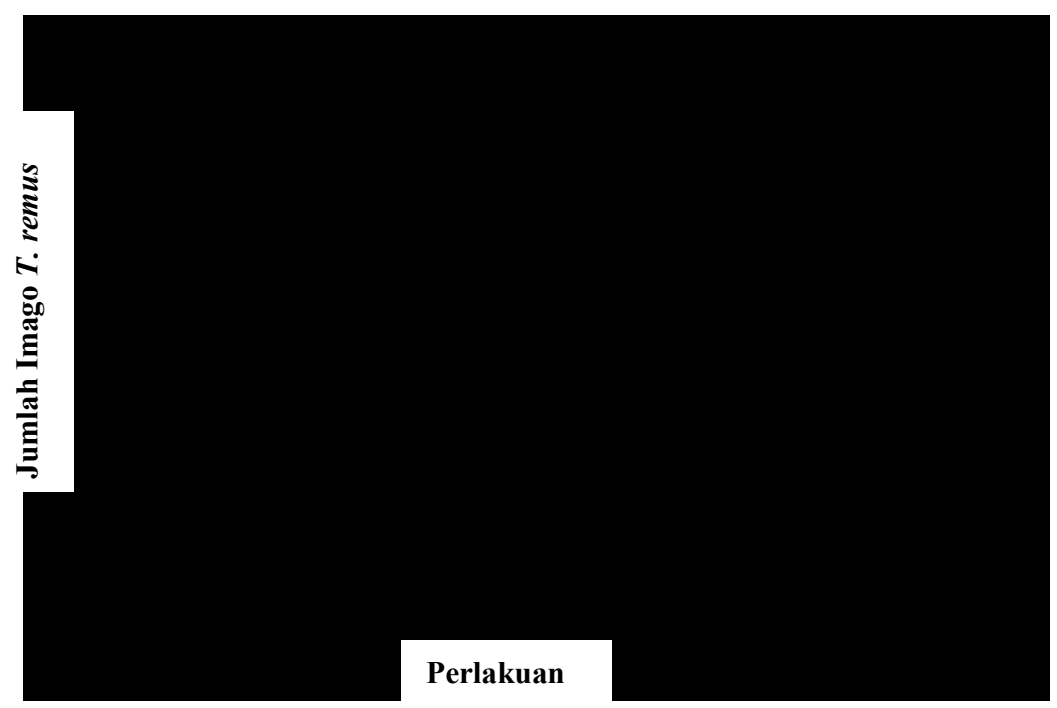

Gambar 6. Jumlah peningkatan imago T. remus pada perlakuan yang berbeda

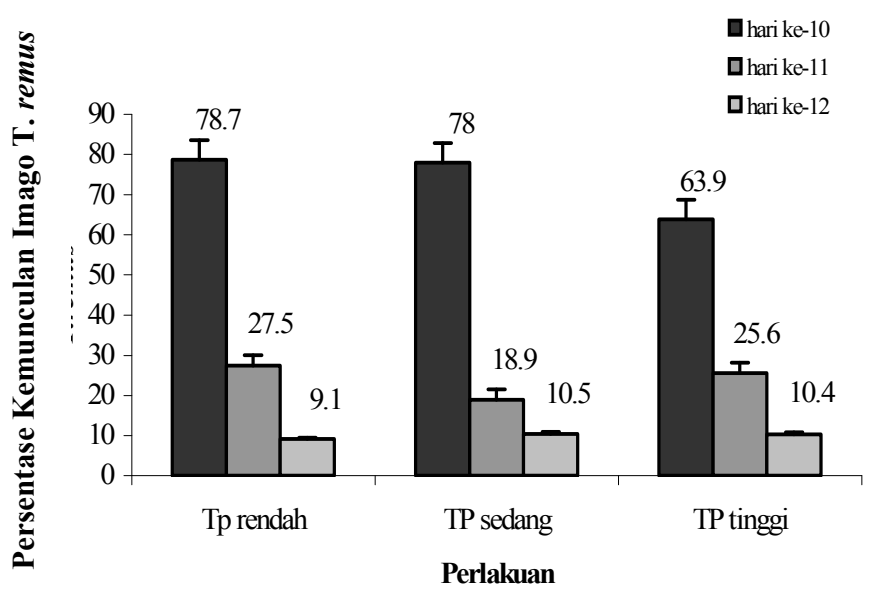

Gambar 7. Rata-rata persentase kemunculan imago T. remus/ hari pada tahap 1 pemberian T. remus

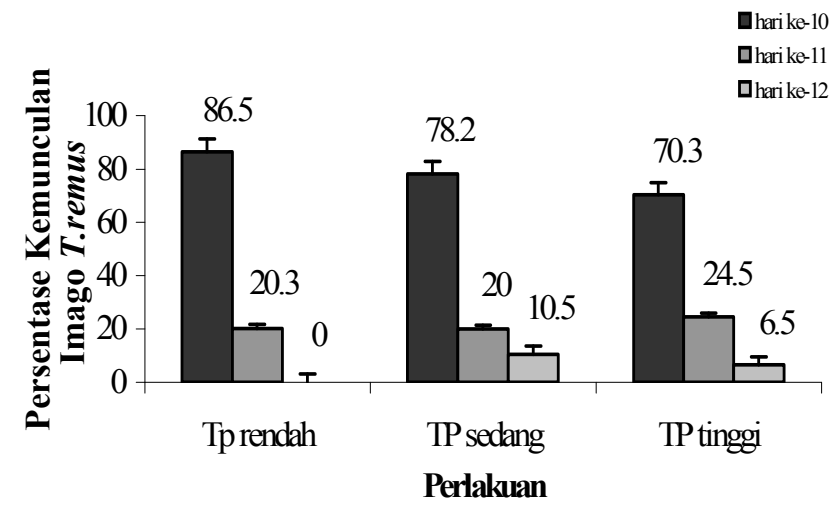

Gambar 8. Rata-rata persentase kemunculan imago T. remus/hari pada tahap 2 pemberian T. remus 
pemberian $T$. remus pada perlakuan. Pada tahap pertama, 64 imago $T$. remus yang muncul pada TP rendah 78,7\%-nya muncul pada hari ke-10, 27,2\% hari ke-11 dan 9,1\% hari ke-12. Pada TP sedang, $78 \%$ dari 68 imago muncul pada hari ke-10, 18,9\% hari ke-11 dan 10,5\% hari ke-12. Pada TP tinggi, 63,9\% dari 302 imago muncul pada hari ke-10, 25,6\% hari ke-11, dan $10,4 \%$ pada hari ke-12.

Pada tahap ke-2 pemberian $T$. remus, pada TP rendah $T$. remus muncul $86,5 \%$ hari ke-10 dan 20,3\% pada hari ke-11 dari 31 imago yang muncul. Pada TP sedang, 78,2\% T. remus muncul pada hari ke-10, 20\% pada hari ke-11, dan $10,5 \%$ pada hari ke-12 dari 41 imago yang muncul. Pada TP tinggi, 70,3\% muncul pada hari ke-10, 24,5\% pada hari ke-11, dan $6,5 \%$ pada hari ke-12 dari 149 imago yang muncul.

Persentase kemunculan imago dari kedua tahap menunjukkan bahwa imago $T$. remus yang muncul sangat tinggi pada hari ke -10 setelah peletakan telur, jumlah imago yang muncul menjadi semakin menurun dengan bertambahnya hari. Keefektifan $T$. remus juga terkait dengan jenis kelamin imago. Banyaknya imago betina yang muncul akan lebih menguntungkan $T$. remus untuk melanjutkan keturunan karena hanya imago betina yang mampu menghasilkan telur dan melakukan parasitisasi. Tabel 4 memperlihatkan sex rasio yang terjadi pada setiap perlakuan. Pada tabel tampak bahwa kemunculan imago jantan mencapai 5,2 kali lebih banyak dari imago betina. Hal ini semakin memperjelas bahwa imago betina yang muncul lebih rendah daripada jantan.

$T$. remus yang digunakan adalah yang berumur 1 hari dan bertelur pada hari yang sama. Dapat diasumsikan bahwa $T$. remus sebagai serangga proovigenik, karena diduga imago yang muncul membawa serta telur yang sudah matang. $T$. remus juga diduga berstrategi reproduksi arrhenotoky.

Tabel 4. Nisbah kelamin imago T. remus yang muncul pada perlakuan yang berbeda

\begin{tabular}{ccccccc}
\hline \hline \multirow{2}{*}{$\begin{array}{c}\text { Per- } \\
\text { lakuan }\end{array}$} & \multicolumn{4}{c}{ Tahap 1 } & \multicolumn{3}{c}{ Tahap 2 } \\
\cline { 2 - 7 } & + & $\sigma^{\lambda}$ & $\begin{array}{c}\text { Nisbah } \\
\text { Kelamin }\end{array}$ & + & $\sigma^{\lambda}$ & $\begin{array}{c}\text { Nisbah } \\
\text { Kelamin }\end{array}$ \\
\hline TP rendah & 18 & 46 & $1: 2,5$ & 9 & 22 & $1: 2,4$ \\
TP sedang & 11 & 57 & $1: 5,2$ & 7 & 34 & $1: 4,8$ \\
TP tinggi & 72 & 230 & $1: 3,2$ & 52 & 97 & $1: 1,8$ \\
\hline
\end{tabular}


Apabila imago betina yang muncul tidak terbuahi, maka keturunannya akan berkelamin jantan. Hal tersebut menyebabkan adanya bias jantan pada keturunan T. remus.

Keberadaan populasi T. remus ternyata sangat mempengaruhi populasi S. exigua, seperti halnya parasitoid lain yang telah dilaporkan mampu mengendalikan inangnya. Cobo (1996) dalam Costa (1999) melaporkan bahwa di Colombia parasitoid Galeopsomyia fausta (Hymenoptera: Chalcidoidea) mampu menekan populasi Phyllocnistis citrella (Lepidoptera: Gracillariidae) hingga $87,77 \%$ pada fase pupa. Keinmeesuke et al. (1990) melaporkan bahwa di Thailand Trichogrammatoidea bactrae dapat menekan populasi telur Plutella xylostella 16,2 - 45,2\%, Cotesia plutellae menekan populasi larva $P$. xylostella $6,1-32,4 \%$.

T. remus mampu menekan populasi inangnya pada fase telur. Hal ini tampak dari persentase keberhasilan hidup $S$. exigua yang semakin menurun dan angka kematian $S$. exigua yang semakin tinggi (pada fase telur) dengan semakin tingginya populasi $T$. remus. Kematian $S$. exigua pada fase telur terlihat semakin meningkat dengan semakin tingginya tingkat parasitisasi. Hal ini dapat dilihat dari kemampuan $T$. remus yang dapat menurunkan populasi inang hingga 9,20\% (tahap 1) dan 6,77\% (T2) pada
TP rendah, 23,41\% (T1) dan 23,08\% (T2) pada TP sedang, 47,97\% (T1) dan $44,20 \% \quad$ (T2) pada TP tinggi. Berdasarkan informasi ini dapat dikatakan bahwa untuk melakukan pelepasan $T$. remus dilapang dapat diperkirakan berapa jumlah $T$. remus yang akan dilepaskan. Pada fase lanjut $S$. exigua juga terjadi kematian yang cukup tinggi, namun tidak memperlihatkan peningkatan kematian dengan semakin tingginya tingkat parasitisasi. Hal ini menunjukkan bahwa kematian pada tiap-tiap fase lanjut tidak dipengaruhi oleh faktor parasitisasi tetapi lebih dipengaruhi oleh kondisi lingkungan seperti suhu, keadaan tanaman bawang daun, dan ketahanan S. exigua sendiri.

Berdasarkan hasil penelitian yang telah didapat tampak bahwa $T$. remus cukup efektif dalam mengendalikan populasi $S$. exigua. Keefektifan $T$. remus terlihat dari populasi keturunan $T$. remus yang meningkat hingga 24,1 kali dari 22 imago betina (TP tinggi), 16,8 kali dari 14 imago betina (TP sedang), dan 13,9 kali dari 8 imago betina (TP rendah). Peningkatan populasi keturunan ini menunjukkan bahwa semakin tinggi populasi $T$. remus yang dilepaskan maka semakin tinggi populasi keturunan sehingga akan lebih efektif untuk mengendalikan $S$. exigua di lapang dengan mengadakan pelepasan $T$. remus dalam jumlah yang besar. 
Berdasarkan data hasil penelitian juga tampak bahwa populasi imago yang muncul sangat tinggi pada hari ke -10 setelah peletakkan telur. Hal ini akan mempengaruhi disaat pelepasan $T$. remus dilapang. Jadi dalam prakteknya harus dilakukan perhitungan secara akurat mengenai berapa lama imago dapat bertahan di lapangan, kapan pelepasan harus dimulai lagi, dan kapan imago yang baru akan muncul. Terkait strategi pelepasan musuh alami di lapang, T. remus dapat digunakan baik dalam strategi inundasi maupun inokulasi. Pada strategi inundasi, persiapan pembiakan di laboratorium harus disesuaikan (singkronisasi) dengan siklus hidup hama di lapang. Sejumlah besar biakan $T$. remus disiapkan 10 hari sebelum hama $S$. exigua meletakkan telurnya. Hal serupa juga disiapkan untuk strategi inokulasi. Namun, dengan penambahan bahwa digunakan generasi yang berikutnya (bila di lab dibiakkan parental, dan bila pelepasan pertama menggunakan F1, maka pelepasan berikutnya menggunakan F3). Bila $T$. remus diharapkan bisa menetap di lapang, maka ketersediaan inang alternatif sangat dibutuhkan untuk mengakomodasi kebutuhan reproduksi musuh alami. Selain itu, keefektifan $T$. remus juga dipengaruhi oleh nisbah kelamin imago. Semakin banyak imago betina yang muncul maka $T$. remus akan semakin efektif dalam mengendalikan inangnya. Data menunjukkan bahwa imago betina yang muncul sangat rendah. Kemunculan imago betina yang rendah dapat diakibatkan oleh adanya betina yang tidak kawin. Rendahnya imago betina yang muncul pada setiap perlakuan menunjukkan bahwa $T$. remus akan sulit melanjutkan keturunannya sehingga mengakibatkan kemampuan parasitisasinya menjadi rendah. Oleh karena $T$. remus memiliki strategi reproduksi arrhenotoky, sementara keturunan betina sangat diharapkan guna keberlanjutan siklus hidup atau menetapnya di habitat, maka dalam pelepasan harus dipastikan bahwa imago yang dilepas adalah imago yang telah kopulasi dan siap melatakkan telur (nisbah kelamin diharapkan tidak bias jantan).

\section{KESIMPULAN}

T. remus merupakan parasitoid telur yang efektif mengendalikan $S$. exigua. Semakin tinggi tingkat parasitisasi, semakin rendah peluang hidup populasi $S$. exigua pada fase telur. Pada perbandingan imago $S$. exigua dengan $T$. remus 1:11 penurunan populasi $S$. exigua mencapai $46,5 \%$, pada perbandingan 1:7 penurunan populasi $S$. exigua mencapai 28,6\%, dan pada perbandingan 1:4 populasi $S$. exigua menurun hingga 12,95\%. Imago $T$. remus betina mampu meningkatkan 
populasi keturunannya hingga 24,1 kali dari populasi awal (11 imago), 16,8 kali dari 7 imago, dan 13,9 kali dari 4 imago. Walaupun kematian pupa cukup tinggi, T. remus tetap mampu menurunkan populasi $S$. exigua.

\section{DAFTAR PUSTAKA}

Buchori D, Pudjianto, Sari A. 1997. Pengaruh perbedaan inang pada bionomi Telenomus spodopterae Dodd. (Hymenoptera: Scelionidae): dampak terhadap biologi dan kebugaran. Jurusan Hama dan Penyakit Tumbuhan. Fakultas Pertanian. Institut Pertanian Bogor. Bulletin Hama dan Penyakit Tumbuhan 9 (2): 8 18.

Costa LAN et al. 1999. Indigenous parasitoids (Hymenoptera: Chacidoidea) of Phyllocnistis citrella Stainton (Lepidoptera: Gracillariidae) in Jaguariuna, Sao Paulo State, Brazil: preliminary results. Berlin: Blackwell Wissenscahfts Verlag. Journal Appl. Ent. 123: $237-240$.

Hartini S. 1995. Pengetahuan, sikap, dan tindakan petani dalam pengelolaan organisme pengganggu tanaman bawang daun (Allium fistulatum L.) di Kecamatan Maja, Kabupaten Majalengka, Jawa barat. Jurusan Hama dan Penyakit Tumbuhan. Fakultas Pertanian. Institut Pertanian Bogor.

Himawati S. 1998. Pengamatan parasitoid larva Spodoptera exigua Hubbner dan penyakit bercak ungu (Alterlaria porri)

pada bawang daun di

kecamatan Kadu dampit,

Kabupaten Sukabumi, jawa

barat. Jurusan Hama dan

Penyakit Tumbuhan. Fakultas

Pertanian. Institut Pertanian

Bogor.

Kalshoven LGE. 1981. The Pest of Crop in Indonesia. PT Ichtiar Baru-Van Hoeve. Jakarta.

Keinmeesuke et al. 1990. The table of diamondback moth and its egg parasite Trichogrammatidea bactrae in Thailand. Departement of Entomology. Thailand: Bangkok.

Metcalf Cl, Flint WP. 1982. Destructive and Usefull Insect Their Habits and Control. Mc. Graw. Hill Book Company. Inc New Delhi.

Nurmayanti I. 1998. Pengaruh ekstrakbij srikaya (Anonna squamosa L.) (Annonaceae) terhadap kepadatan populasi parasitoid Diadegma semiclausum Hellen (Hymenoptera: Ichneumonidae) di lapang. Jurusan Hama dan Penyakit Tumbuhan. Fakultas Pertanian. Institut Pertanian Bogor.

Pujiastuti ME. 2001. Perubahan penerimaan inang dan kebugaran Telenomus remus Nixon (Hymenoptera: Scelionidae) akibat penyimpanan telur Spodoptera litura Fabricus (Lepidoptera: Noctuidae) pada suhu dan waktu yang berbeda. Jurusan Hama dan Penyakit Tumbuhan, Fakultas Pertanian. Institut Pertanian Bogor. 
Rudiana Y. 1995. Statistik demografi Spodoptera exigua [Hubbner] (Lepidoptera: Noctuidae) pada tanaman bawang (Allium sp). Jurusan Hama dan Penyakit Tumbuhan. Fakultas Pertanian. Institut Pertanian Bogor.

Sari A. 1997. Perkembangan dan biologi reproduksi Telenomus Spodopterae (Hymenoptera: Scelionidae) pada inang Spodoptera exigua (Hbn.) (Lepidoptera: Noctuidae). Jurusan Hama dan Penyakit Tumbuhan. Fakultas Pertanian. Institut Pertanian Bogor.
Sari ME. 2001. Penyimpanan telur Spodoptera litura Fabricus (Lepidoptera: Noctuidae) pada suhu rendah dan kepadatan betina parasitoid, Telenomus remus Nixon (Hymenoptera: Scelionidae): Pengaruhnya terhadap kebugaran dan nisbah kelamin parasitoid. Jurusan Hama dan Penyakit Tumbuhan, Fakultas Pertanian. Institut Pertanian Bogor.

Wibowo S. 1999. Budidaya Bawang bawang putih, bawang merah, bawang bombay. Penebar Swadaya. Jakarta. 